\title{
Effect of actinomycin D on uterine prostaglandin production and oestrous cycle length in guinea-pigs
}

\author{
N. L. Poyser \\ Department of Pharmacology, University of Edinburgh, 1 George Square, \\ Edinburgh EH8 9JZ, U.K.
}

\begin{abstract}
Summary. Intrauterine, but not systemic, administration of actinomycin D on Day 10 increased oestrous cycle length in guinea-pigs. Peripheral plasma progesterone levels remained elevated during these lengthened cycles presumably because luteal life-span had been extended. Prostaglandin (PG) F-2 $\alpha$ production in vitro, on Day 15 , by the uterus of guinea-pigs which had received intrauterine actinomycin $D$ was much lower than control values. This decrease in PG production was not due to lack of precursor, increased metabolism, re-direction of synthesis towards PGE-2, or a direct inhibition by actinomycin $\mathrm{D}$ of the conversion of arachidonic acid to PGs. The effects of actinomycin $\mathrm{D}$ treatment were not reversed by oestradiol.

It is proposed that actinomycin D prevents the increase in uterine PG synthetase levels that normally takes place after Day 11, thereby reducing uterine PGF-2 $\alpha$ synthesis and output in vivo, and resulting in luteal maintenance and longer oestrous cycles.
\end{abstract}

\section{Introduction}

There is much evidence that prostaglandin (PG) F-2 $\alpha$ is the uterine luteolytic hormone in several species of mammal (see Horton \& Poyser, 1976). In the guinea-pig, utero-ovarian venous plasma levels of PGF-2 $\alpha$ increase from about Day 11 or 12 of the oestrous cycle (Blatchley, Donovan, Horton \& Poyser, 1972; Earthy, Bishop \& Flack, 1975). The in-vitro PGF-2 $\alpha$ production by homogenates of guinea-pig uterus utilizing endogenous precursor also increases from about Day 12, reaching peak production by Day 15 (Poyser, 1972). These in-vitro results have been confirmed by Wlodawer, Kindahl \& Hamberg (1976) who used a microsomal preparation of guinea-pig uterus and exogenous arachidonic acid.

The difference in synthesizing capacity in vitro between days early and late in the cycle is not due to differences in endogenous substrate levels or differences in metabolism (Mitchell, Poyser \& Wilson, 1977). It reflects a genuine increase in the amounts of PGF-2 $\alpha$ synthesized due to an increase in the amount (level) of prostaglandin synthetase within the uterus. The significance of this increase in enzyme levels was investigated by studying the effect of actinomycin $D$, a protein synthesis inhibitor, on the PG synthesizing capacity of the uterus and oestrous cycle length in the guinea-pig.

\section{Materials and Methods}

Virgin guinea-pigs weighing 500-800 $\mathrm{g}$ were examined daily and a vaginal smear was taken when the vaginal membrane was perforate. The first day of the oestrous cycle was taken as the day before the post-ovulatory influx of leucocytes when cornification was at a maximum. All animals had exhibited at least 2 normal cycles before use. 


\section{Experiments}

Experiment 1. On Day 10 of the cycle, 10 guinea-pigs were anaesthetized with pentobarbitone sodium $(35 \mathrm{mg} / \mathrm{kg}$ ). An incision was made in the abdomen and the junction of the two uterine horns was exposed. Each guinea-pig received a $1 \mathrm{ml}$ injection of sterile, normal saline $(9 \mathrm{~g} \mathrm{NaCl} / \mathrm{l})$ into each uterine horn. For 5 of the animals the saline contained $20 \mu \mathrm{g}$ actinomycin D. The body wall and skin of each guinea-pig were stitched, and the animals recovered in 6-8 h: none subsequently showed any side-effects from the operation or drug treatment. A further 5 guinea-pigs received a subcutaneous injection of $40 \mu \mathrm{g}$ actinomycin D (Sigma, Poole) on Day 10 of the cycle: there were again no side-effects of treatment.

Oestrous cycle length was measured in all animals before and after treatment. Peripheral blood was withdrawn into a heparinized syringe by cardiac puncture on Mondays, Wednesdays and Fridays during the pre-treatment, treatment and post-treatment cycles. After centrifugation, the plasma was stored at $-20^{\circ} \mathrm{C}$ until assay for progesterone.

Experiment 2. Fifteen animals were anaesthetized on Day 10 of the cycle, as in Experiment 1. Similarly, 10 guinea-pigs received an injection of $20 \mu \mathrm{g}$ actinomycin $\mathrm{D}$ into each uterine horn, whilst the other 5 guinea-pigs (controls) received intrauterine saline only. A cardiac blood sample was taken from each animal on Day 15 of the cycle, for the analysis of plasma progesterone, and the guinea-pig was then killed. Prostaglandin production by the homogenized uterus and ovaries in vitro was measured, as described previously (Mitchell et al., 1977) using 15 and $10 \mathrm{ml}$ Krebs' solution respectively. However, arachidonic acid (final concentration $3 \mu \mathrm{g} / \mathrm{ml}$ ) was added before incubation to the uterine and ovarian homogenates of 5 actinomycin D-treated guinea-pigs.

Experiment 3. Each of 10 guinea-pigs on Day 10 of the cycle received a subcutaneous injection of $0.4 \mathrm{ml}$ saline $(\mathrm{N}=5)$ or $40 \mu \mathrm{g}$ actinomycin $\mathrm{D}$ in $0.4 \mathrm{ml}$ saline $(\mathrm{N}=5)$. A cardiac blood sample for progesterone determination was taken on Day 15. Prostaglandin production by the uterus and ovaries in vitro was determined as in Exp. 2 (without the addition of arachidonic acid).

Experiment 4. Ten guinea-pigs on Day 10 of the cycle were anaesthetized, and given an intrauterine injection of actinomycin D or saline as in Exp. 1. The 5 animals in each group were injected subcutaneously with $10 \mu \mathrm{g}$ oestradiol benzoate (Sigma, Poole) from Days 11-14. On Day 15, a cardiac blood sample for progesterone determination was withdrawn before the animals were killed. Prostaglandin production by the homogenized uteri and ovaries in vitro (without the addition of arachidonic acid) was determined as before.

Experiment 5. Five guinea-pigs on Day 15 of the cycle were killed and their uteri removed. The two uterine horns were separated and weighed and each was homogenized in $7.5 \mathrm{ml}$ Krebs' solution. Actinomycin D $(20 \mu \mathrm{g})$ was added to the homogenate of one uterine horn from each pair. Prostaglandin production in vitro was measured as before.

Experiment 6. Six guinea-pigs on Day 10 of the cycle were anaesthetized, and each exposed uterine horn received an injection of actinomycin D $(20 \mu \mathrm{g})$ or saline as in Exp. 1 (3 animals/group). The animals were killed on Day 15 of the cycle and the uteri and ovaries removed. The two uterine horns were separated, and the ovaries from each animal were also kept separate. Each uterine horn and ovary was weighed and homogenized in 10 and $5 \mathrm{ml} \mathrm{Krebs'}$ solution, respectively. To all homogenates was added $0.5 \mu \mathrm{Ci}\left[{ }^{3} \mathrm{H}\right] \mathrm{PGF}-2 \alpha$ (sp. act. 160 $\mathrm{Ci} / \mathrm{mmol}$; Radiochemical Centre, Amersham, U.K.). Nicotinamide-adenine dinucleotide $\left(\mathrm{NAD}^{+} ; 2 \mathrm{mM}\right)$ and PGF- $2 \alpha(5 \mu \mathrm{g} / \mathrm{ml})$ were added to one uterine and one ovarian homogenate from each animal. All homogenates were incubated, and prostaglandins were extracted as in Exp. 2. The dried extracts were then each dissolved in $0.15 \mathrm{ml}$ methanol and subjected to analysis by thin-layer chromatography by methods described previously (Maule Walker \& Poyser, 1978). The percentage metabolism of PGF-2 $\alpha$ was calculated from the radioactivity recovered, though a correction had to be made for the metabolite due to a loss of a tritium atom from the carbon at position 15 . 
A reference plate onto which had been spotted $10 \mu \mathrm{g}$ PGF- $2 \alpha$ and $10 \mu \mathrm{g}$ 13,14-dihydro-15oxo-PGF- $2 \alpha$ was also analysed and the $R_{F}$ values of PGF-2 $\alpha$ and its main metabolite were calculated.

\section{Assay procedures}

Progesterone was measured by radioimmunoassay using an antibody raised and tested by Dighe \& Hunter (1974) and assessed for its suitability for use in the laboratory by Poyser \& Horton (1975). The antibody had adequate sensitivity (limit $20 \mathrm{pg}$ ) and specificity (see Table 1 in Poyser \& Horton, 1975) and the results obtained in the present study were in the expected range. The intra- and inter-assay coefficients of variation were 10.8 and $12.5 \%$ respectively.

PGF-2 $\alpha$ was measured by radioimmunoassay using an antibody developed in this laboratory (Dighe, Emslie, Henderson, Rutherford \& Simon, 1975). This antibody does not distinguish between PGF-2 $\alpha$ and PGF-1 $\alpha$. However, previous studies which have identified, by gas chromatography and mass spectrometry, the PGs formed by homogenates of guinea-pig uterus showed that neither PGF-1 $\alpha$ nor PGE-1 are produced, since the guinea-pig uterus contains very little $\omega$-dihomo- $\boldsymbol{\gamma}$-linolenic acid (the precursor of the 1 -series prostaglandins) compared with arachidonic acid (the precursor of the 2-series prostaglandins) (see Mitchell et al., 1977). Consequently, in this study, it was highly probable that only PGF- $2 \alpha$ was being measured. The control samples had values in the expected range and parallelism was observed for all samples assayed. The detection limit was $40 \mathrm{pg}$. The intra- and inter-assay coefficients of variation were 10.7 and $10.3 \%$ respectively.

PGE-2 was also measured by radioimmunoassay using an antibody, purchased from the Pasteur Institute (Paris), which has previously been tested and found suitable for use in this laboratory (Mitchell et al., 1977). It cross-reacts significantly (15.1\%) with PGE-1 but, for the reasons given above, it is highly probable that only PGE-2 was being assayed. Again, the results from the control samples were in the expected range and parallelism was shown by all samples in the assay. The detection limit was $4 \mathrm{pg}$. The intra- and inter-assay coefficients of variation were 10.3 and $13.5 \%$ respectively.

\section{Statistical tests}

Results, expressed as mean \pm s.e.m., were analysed by Student's $t$ test.

\section{Results}

Uteri removed from all animals were normal in gross appearance irrespective of whether they had received actinomycin $\mathrm{D}$ or not. Corpora lutea were adjudged to be functional if peripheral plasma progesterone levels were $>1 \mathrm{ng} / \mathrm{ml}$.

\section{Experiment 1}

As shown in Table 1, an intrauterine injection of actinomycin D on Day 10 significantly prolonged both luteal function $(P<0.01)$ and oestrous cycle length $(P<0.01)$, the increases being approximately 2 -fold. Plasma progesterone levels, vaginal opening and vaginal cornification indicated normal post-treatment cycles in only 3 of the 5 treated animals, but the other 2 animals had a normal cycle after the post-treatment cycle.

\section{Experiments 2, 3 and 4}

The results in Table 2 show that the intrauterine administration of actinomycin D significantly reduced uterine PGF and PGE production in vitro, and that this was not due to lack 
Table 1. Mean \pm s.e.m. length (days) of the oestrous cycle and period when progesterone levels are $>1$ $\mathrm{ng} / \mathrm{ml}$ plasma in guinea-pigs (5/group) treated with actinomycin D

\begin{tabular}{|c|c|c|c|c|c|c|}
\hline \multirow[b]{2}{*}{ Treatment } & \multicolumn{3}{|c|}{ Oestrous cycle } & \multicolumn{3}{|c|}{ Progesterone levels $>1 \mathrm{ng} / \mathrm{ml}$} \\
\hline & $\begin{array}{l}\text { Pre-treatment } \\
\text { cycle }\end{array}$ & $\begin{array}{l}\text { Treatment } \\
\text { cycle }\end{array}$ & $\begin{array}{l}\text { Post-treatment } \\
\text { cycle }\end{array}$ & $\begin{array}{l}\text { Pre-treatment } \\
\text { cycle }\end{array}$ & $\begin{array}{l}\text { Treatment } \\
\text { cycle }\end{array}$ & $\begin{array}{l}\text { Post-treatment } \\
\text { cycle }\end{array}$ \\
\hline Saline (intrauterine) & $16 \cdot 6 \pm 0.4$ & $18 \cdot 2 \pm 0.6$ & $16.8 \pm 0.2$ & $10.4 \pm 0.2$ & $10.4 \pm 0.2$ & $10.6 \pm 0.6$ \\
\hline $\begin{array}{r}\text { Actinomycin D } \\
\text { (intrauterine) }\end{array}$ & $16 \cdot 6 \pm 0.6$ & $32 \cdot 6 \pm 5 \cdot 4^{*}$ & $17 \cdot 3 \pm 1 \cdot 2 \dagger$ & $10.0 \pm 0.6$ & $20 \cdot 4 \pm 2 \cdot 2^{*}$ & $10.3 \pm 0.7 \dagger$ \\
\hline $\begin{array}{l}\text { Actinomycin D } \\
\text { (subcutaneous) }\end{array}$ & $17 \cdot 2 \pm 0 \cdot 2$ & $16 \cdot 6 \pm 0.4$ & $16 \cdot 6 \pm 0 \cdot 2$ & $11 \cdot 0 \pm 0.5$ & $10 \cdot 4 \pm 0.7$ & $10 \cdot 2 \pm 0.7$ \\
\hline
\end{tabular}

${ }^{*} P<0.01$ compared with all other groups.

$\dagger$ Mean of 3 guinea-pigs. The other 2 guinea-pigs had anovular cycles of 9 and 13 days, respectively, and plasma progesterone did not exceed $0.7 \mathrm{ng} / \mathrm{ml}$.

Table 2. Mean \pm s.e.m. production of prostaglandin (PG) $F$ and $E$ in vitro by the uterus and ovaries, and peripheral plasma progesterone levels, in guinea-pigs (5/group) on Day 15 after intrauterine (Exps 2 and 4) or systemic (Exp. 3) administration of actinomycin D

\begin{tabular}{|c|c|c|c|c|c|}
\hline \multirow[b]{3}{*}{ Treatment } & \multicolumn{4}{|c|}{ PG production (ng/100 mg tissue) } & \multirow{3}{*}{$\begin{array}{l}\text { Progesterone } \\
\text { (ng/ml) }\end{array}$} \\
\hline & \multicolumn{2}{|c|}{ Uterus } & \multicolumn{2}{|c|}{ Ovary } & \\
\hline & PGF & PGE & PGF & PGE & \\
\hline $\begin{array}{l}\text { Experiment } 2 \\
\text { Control } \\
\text { Actinomycin D } \\
\text { Actinomycin D plus } \\
\text { exogenous arachidonic } \\
\text { acid }\end{array}$ & $\begin{array}{c}112 \cdot 2 \pm 12 \cdot 4 \\
23 \cdot 6 \pm 5 \cdot 1 \dagger \\
27 \cdot 1 \pm 4 \cdot 0^{\dagger}\end{array}$ & $\begin{array}{l}7.5 \pm 1.2 \\
3.7 \pm 0.8^{*} \\
3.4 \pm 0.4^{*}\end{array}$ & $\begin{array}{ll}26 \cdot 1 \pm 2.6 \\
30 \cdot 0 \pm & 3 \cdot 0 \\
33 \cdot 4 \pm & 7 \cdot 2\end{array}$ & $\begin{array}{l}5.2 \pm 0.6 \\
6.4 \pm 0.6 \\
7.0 \pm 1.6\end{array}$ & $\begin{array}{l}0.4 \pm 0.1 \\
3.8 \pm 0.7 \dagger \\
5.4 \pm 0.6 \dagger\end{array}$ \\
\hline $\begin{array}{l}\text { Experiment } 3 \\
\text { Control } \\
\text { Actinomycin D }\end{array}$ & $\begin{array}{l}139.9 \pm 17.3 \\
122.0 \pm 8.4\end{array}$ & $\begin{array}{l}6.6 \pm 0.9 \\
5.9 \pm 0.7\end{array}$ & $\begin{array}{l}30.9 \pm 4.4 \\
30.7 \pm 1.3\end{array}$ & $\begin{array}{l}4.9 \pm 0.5 \\
4.7 \pm 0.4\end{array}$ & $\begin{array}{l}0.6 \pm 0.1 \\
0.7 \pm 0.2\end{array}$ \\
\hline $\begin{array}{l}\text { Experiment 4 } \\
\text { Control } \\
\text { Actinomycin D }\end{array}$ & $\begin{array}{c}139.7 \pm 22.7 \\
35.3 \pm 5.3 \dagger\end{array}$ & $\begin{array}{c}12.9 \pm 1.5 \\
5.8 \pm 0.8 \dagger\end{array}$ & $\begin{array}{l}43 \cdot 7 \pm 13 \cdot 3 \\
30.4 \pm 4.6\end{array}$ & $\begin{array}{l}7 \cdot 5 \pm 2 \cdot 2 \\
5.0 \pm 0.3\end{array}$ & $\begin{array}{l}0.4 \pm 0.1 \\
6.6 \pm 0.6 \dagger\end{array}$ \\
\hline
\end{tabular}

Compared with respective control group, ${ }^{*} P<0.05, \dagger P<0.01$.

of precursor (Exp. 2). Prostaglandin production by the ovaries was not affected. Plasma progesterone levels in guinea-pigs treated with intrauterine actinomycin $\mathrm{D}$ were higher than in control animals. When the actinomycin D was given systemically (Exp. 3) PG production and progesterone levels were unaltered.

Treatment with oestradiol benzoate (Exp. 4) did not prevent the decrease in uterine PG production and the elevation in plasma progesterone levels in guinea-pigs treated with intrauterine actinomycin $\mathrm{D}$.

\section{Experiment 5}

The amounts of PGF produced by uterine horns in the presence and absence of actinomycin D were $78.8 \pm 12.3$ and $83.4 \pm 12.0 \mathrm{ng} / 100 \mathrm{mg}$ tissue respectively. Similarly, the amounts of PGE produced were $10.0 \pm 2.4$ and $9.4 \pm 2.8 \mathrm{ng} / 100 \mathrm{mg}$ tissue, respectively. 


\section{Experiment 6}

The extracts from the uterine samples which contained NAD ${ }^{+}$and exogenous PGF- $2 \alpha$ produced two radioactive zones on the t.l.c. plates. The zone containing the larger proportion of radioactivity coincided with authentic PGF- $2 \alpha\left(R_{F}=0.34\right)$. The other zone had the same $R_{F}$ value $(0.58)$ as 13,14 -dihydro-15-oxo-PGF-2 $\alpha$. Percentage metabolism by both groups was about $18 \%$ (Table 3 ). There was no detectable metabolism $(<5 \%)$ by uterine samples incubated without $\mathrm{NAD}^{+}$and exogenous PGF-2a, since only one radioactive zone (at $R_{F}=0.34$ ) was located on the t.l.c. plates.

Total metabolism of PGF- $2 \alpha$ by the ovary, in the presence of $\mathrm{NAD}^{+}$and exogenous PGF$2 \alpha$, was similar to that by the uterus (Table 3). The significant difference in the total amount of PGF-2 $\alpha$ metabolized by the ovaries was removed by correction for weight of tissue. Metabolism of PGF- $2 \alpha$ by ovarian tissue in the absence of $\mathrm{NAD}^{+}$was not detectable $(<5 \%)$.

Table 3. Mean \pm s.e.m. percentage metabolism of $\left[{ }^{3} \mathrm{H}\right]$ prostaglandin $\mathrm{F}-2 \alpha$ by uterine and ovarian homogenates in the presence of $\mathrm{NAD}^{+}(2 \mathrm{~mm})$ and exogenous PGF- $2 \alpha(3 \mu \mathrm{g} / \mathrm{ml})$ from guinea-pigs treated with intrauterine actinomycin $\mathrm{D}$

\begin{tabular}{lccccc}
\hline & \multicolumn{2}{c}{ Uterus } & & \multicolumn{2}{c}{ Ovary } \\
\cline { 2 - 3 } \cline { 5 - 6 } Treatment & Total & Per $100 \mathrm{mg}$ tissue & & Total & Per 10 mg tissue \\
\hline Saline (control) & $17.2 \pm 2.2$ & $4.6 \pm 0.9$ & & $12.4 \pm 0.8$ & $2.4 \pm 0.4$ \\
Actinomycin D & $18.8 \pm 5.9$ & $4.2 \pm 1.5$ & & $19.1 \pm 1.5^{*}$ & $3.8 \pm 0.7$ \\
\hline
\end{tabular}

${ }^{*} P<0.05$ compared with control group.

\section{Discussion}

The PGF- $2 \alpha$ synthesizing capacity of the guinea-pig uterus in vitro increases from about 40 $\mathrm{ng} / 100 \mathrm{mg}$ tissue during mid-cycle to about $120 \mathrm{ng} / 100 \mathrm{mg}$ tissue by Day 15 (Poyser, 1972). This study has shown that treatment of guinea-pigs with actinomycin D injected directly into the uterus on Day 10 prevents this increase in uterine prostaglandin production. Systemic administration of actinomycin D was without effect. The decrease in uterine PGF-2 $\alpha$ production observed after intrauterine treatment was not due to increased metabolism of the PGF-2 $\alpha$ or redirection of synthesis towards PGE-2. The decrease in uterine PGF-2 $\alpha$ synthesizing capacity in vitro was reflected in vivo by the peripheral plasma progesterone levels remaining high for a longer period than normal, presumably due to prolongation of luteal function, and by increased oestrous cycle length. It would appear, therefore, that an increase in uterine PGF- $2 \alpha$ synthesizing capacity is important for the luteolytic action of the uterus to occur and, if prevented, luteal regression does not take place. This reduction in uterine PGF- $2 \alpha$ synthesizing capacity, resulting in decreased uterine PGF-2 $\alpha$ output and luteal maintenance, has previously been observed during early pregnancy in the guinea-pig (Maule Walker \& Poyser, 1974, 1978; Blatchley, Maule Walker \& Poyser, 1975). These effects have been attributed to the action of an antiluteolytic factor secreted by the conceptus. However, the antiluteolytic factor and actinomycin D cannot be acting in the same manner to prevent the increase in uterine PGF- $2 \alpha$ synthesizing capacity, since the former can be overcome by oestradiol (Maule Walker, 1976), while the latter cannot (present study). Treatment of sheep with intrauterine actinomycin D also extends luteal function and oestrous cycle length, and this too is not surmountable by oestradiol treatment (French \& Casida, 1973). Whether actinomycin D affects PG synthetase levels in the sheep uterus is not known. 
In ovariectomized guinea-pigs, oestradiol treatment increases the PGF- $2 \alpha$ synthesizing capacity of the uterus (Naylor \& Poyser, 1975). Since oestradiol output from the guinea-pig ovary increases from Day 11 up to the end of the cycle (Joshi, Watson \& Labhsetwar, 1973), oestradiol is probably the physiological stimulus which causes the increase in uterine PGF-2 $\alpha$ synthesizing capacity. Actinomycin D acts to inhibit DNA-dependent RNA synthesis, so this metabolic step would appear to be essential in the mechanism by which oestradiol increases uterine PGF-2 $\alpha$ synthesizing capacity. The ultimate effect of actinomycin D treatment is to prevent fresh protein synthesis including, therefore, the synthesis of enzymes. The present invitro studies showed that intrauterine actinomycin $\mathbf{D}$ treatment cannot seriously be interfering with the availability of arachidonic acid in vitro since the addition of exogenous substrate did not overcome the reduction in uterine PGF- $2 \alpha$ production. It is proposed therefore that actinomycin $D$ prevents the increase in PG synthetase levels in the guinea-pig uterus, which normally takes place after about Day 11 under the influence of oestradiol released from the ovary. Furthermore, in-vivo findings would suggest that this increase in enzyme levels (Pathway 2; see Text-fig. 1) is critically important for increased uterine PGF- $2 \alpha$-synthesis and output to occur, and consequently for luteal regression to take place. Since the synthesis of PGF- $2 \alpha$ and PGE- 2 is reduced by actinomycin $D$, the enzyme affected in the prostaglandin synthetase complex may be fatty acid cyclo-oxygenase, although further study is required.

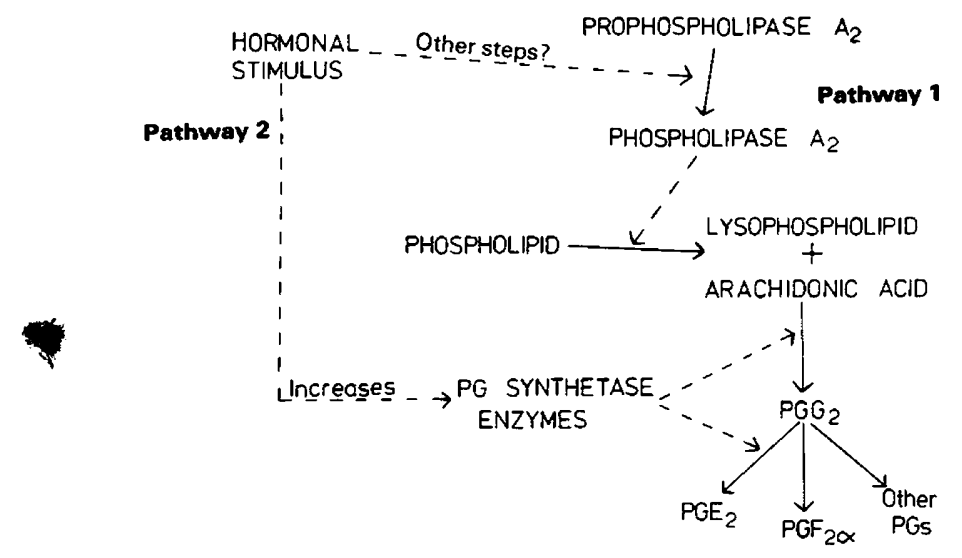

Text-fig. 1. Proposed control mechanisms involved in the synthesis of prostaglandins by the guinea-pig uterus.

The levels of free arachidonic acid in tissues are believed to be too low for PG synthesis to occur and arachidonic acid has therefore to be released from some bound source. However, the absolute level of the free arachidonic acid in the guinea-pig uterus available for conversion to prostaglandin is not known. Consequently, whether activation of Pathway 1 (see Text-fig. 1) in the guinea-pig uterus is a prerequisite for prostaglandin synthesis needs to be investigated.

Intrauterine or systemic treatment of guinea-pigs with actinomycin D did not affect PG production by the ovary, the nearest organ to the uterus. The amounts of PGF-2 $\alpha$ produced were similar to those reported by Sharma, Wilson \& Pugh (1976). (Day 15 in this study is equivalent to about Day -2 in their study.) However, PGE-2 production was about 5 times lower in the present study. The reasons for this discrepancy are not clear, although different antisera were used in the radioimmunoassays. Sharma et al. (1976) found prostaglandin production by the ovary to increase sharply after Day -2 . It would be interesting to see if this is also affected by local actinomycin D administration. In rat isolated Graafian follicles, the LH-induced increase in prostaglandin levels is prevented by pre-treatment with actinomycin D (Zor, Strulovici, Nimrod 
\& Lindner, 1977). These authors proposed that an increase in prostaglandin synthetase enzymes is responsible for the increase in prostaglandin levels in rat follicles.

In conclusion, the intrauterine administration of actinomycin $\mathrm{D}$ to guinea-pigs prevented the increase in uterine prostaglandin synthesizing capacity which takes place after Day 11 . It is proposed that the actinomycin D, by inhibiting DNA-dependent RNA synthesis, prevented the increase in the amount of one or more enzymes in the prostaglandin synthetase complex. However, due to the lack of specificity of actinomycin D on protein synthesis, other mechanisms of action (such as a reduction in uterine oestradiol receptors and/or enzymes regulating arachidonic acid uptake and release) which contributed to the effect observed cannot be ruled out.

This study was supported by the M.R.C. The technical assistance of Miss A. Pelanis, Miss L. Gilchrist and Miss S. North is greatly appreciated. Authentic prostaglandins were kindly supplied by the Upjohn Company, U.S.A.

\section{References}

Blatchley, F.R., Donovan, B.T., Horton, E.W. \& Poyser, N.L. (1972) The release of prostaglandins and progesterone into the utero-ovarian venous blood of guinea-pigs during the oestrous cycle and following oestrogen treatment. J. Physiol., Lond. 228, 69-88.

Blatchley, F.R., Maule Walker, F.M. \& Poyser, N.L. (1975) Progesterone, prostaglandin $F_{2 \alpha}$, and oestradiol in the utero-ovarian venous plasma of nonpregnant and early, unilaterally pregnant guinea-pigs. J. Endocr. 67, 225-229.

Dighe, K.K. \& Hunter, W.M. (1974) A solid-phase radioimmunoassay for plasma progesterone. Biochem. J. 142, 219-231.

Dighe, K.K., Emslie, H.A., Henderson, L.K., Rutherford, F. \& Simon, L. (1975) The development of antisera to prostaglandins $B_{2}$ and $F_{2 \alpha}$ and their analysis using solid-phase and double antibody radioimmunoassay methods. Br. J. Pharmac. 55, 503514.

Earthy, M., Bishop, C. \& Flack, J.D. (1975) Progesterone and prostaglandin $F$ concentration in utero-ovarian venous plasma of cyclic guinea-pigs. $J$. Endocr. 64, 11 P.

French, L.R. \& Casida, L.E. (1973) Effect of actinomycin on corpus luteum regression in ewes. J. Anim. Sci. 37, 1218-1221.

Horton, E.W. \& Poyser, N.L. (1976) Uterine luteolytic hormone: a physiological role for prostaglandin $\mathbf{F}_{2 \alpha}$. Physiol. Rev. 56, 595-651.

Joshi, H.S., Watson, D.J. \& Labhsetwar, A.P. (1973) Ovarian secretion of oestradiol, oestrone, 20dihydroprogesterone and progesterone during the oestrous cycle of the guinea-pig. J. Reprod. Fert. 35, 177-182.

Maule Walker, F.M. (1976) Effect of uterine transection or oestradiol treatment on the production of prostaglandin $F_{2 \alpha}$ by the day 15 pregnant guinea-pig uterus. Advances in Prostaglandin and Thromboxane
Research, Vol. 2, p. 898. Eds B. Samuelsson \& R. Paoletti. Raven Press, New York.

Maule Walker, F.M. \& Poyser, N.L. (1974) Production of prostaglandins by the early pregnant guinea-pig uterus in vitro. J. Endocr. 61, 265-271

Maule Walker, F.M. \& Poyser, N.L. (1978) The metabolism of prostaglandins by the guinea-pig uterus with particular reference to corpus luteal maintenance in early pregnancy. Br.J. Pharmac. 62 , 177-183.

Mitchell, S., Poyser, N.L. \& Wilson, N.H. (1977) Effect of $p$-bromophenacyl bromide, an - inhibitor of phospholipase $A_{2}$, on arachidonic acid release and prostaglandin synthesis by the guinea-pig uterus in vitro. Br. J. Pharmac. 59, 107-113.

Naylor, B. \& Poyser, N.L. (1975) Effect of oestradiol and progesterone on the in vitro production of prostaglandin $\mathrm{F}_{2 a}$ by the guinea-pig uterus. $B r . J$. Pharmac. 55, 229-232.

Poyser, N.L. (1972) Production of prostaglandins by the guinea-pig uterus. J. Endocr. 54, 147-159.

Poyser, N.L. \& Horton, E.W. (1975) Plasma progesterone levels in guinea-pigs actively immunized against prostaglandin $F_{2 \alpha}$, hysterectomized or treated with intra-uterine indomethacin. $J$. Endocr. 67, 81-88.

Sharma, S.C., Wilson, C.M.W. \& Pugh, D.M. (1976) In vitro production of prostaglandins $E$ and $F$ by the guinea-pig ovarian tissue. Prostaglandins 11, 555568.

Wlodawer, P., Kindahl, H. \& Hamberg, M. (1976) Biosynthesis of prostaglandin $F_{2 \alpha}$ from arachidonic acid and prostaglandin endoperoxides in the uterus. Biochim. Biophys. Acta 431, 603-614.

Zor, U., Strulovici, B., Nimrod, A. \& Lindner, H.R. (1977) Stimulation by cyclic nucleotides of prostaglandin $\mathrm{E}$ production in isolated Graafian follicles. Prostaglandins 14, 947-960. 